Ann. Biol. anim. Bioch. Biophys., 1979, 19 (6), 1713-1723.

\title{
lodohormones in the serum of chick embryos and post-hatching chickens as influenced by incubation temperature. Relationship with the hatching process and thermogenesis
}

\author{
par E. DECUYPERE *, E. J. NOUWEN, E. R. KÜHN, R. GEERS, H. MICHELS. \\ Laboratory for Ecophysiology of Domestic Animals, Faculty of \\ Agricultural Sciences and Laboratory of Comparative Endocrinology, \\ Department of Biology, Catholic University of Leuven \\ 3030 Leuven, Belgium.
}

\begin{abstract}
Summary. Serum levels of triiodothyronine $\left(T_{3}\right)$ and thyroxine $\left(T_{4}\right)$ were measured by RIA in developing chick embryos of the Rhode Island Red strain incubated at different temperatures in a forced-draught laboratory incubator. A low incubation temperature resulted in a longer incubation period, whereas eggs incubated at a higher temperature hatched sooner. In all the temperature groups, serum $\mathrm{T}_{3}$ and $\mathrm{T}_{4}$ levels increased during the incubation period studied. Whatever the total duration of incubation within the experimental conditions, maximal serum $\mathrm{T}_{3}$ and $\mathrm{T}_{4}$ levels were always obtained the day of pipping. Embryos having perforated the air-space membrane the day before pipping showed elevated serum $T_{3}$, but not $T_{4}$, levels as compared to embryos without perforation. The presence of high serum $\mathrm{T}_{3}$ levels in chick embryos after perforation of the air-space membrane, and the sharp increase in the $T_{3} / T_{4}$ ratio before pipping were indicative of the important role of $T_{3}$ in the processes of pipping and hatching. After days 16 to 17 , depending on the incubation temperature, a plateau for heat production (measured by indirect calorimetry) was reached while serum $T_{3}$ and $T_{4}$ levels were still increasing. Following the event of pipping, there was a rapid increase in heat production. A plateau might be due to the physical impossibility of each embryo to react upon an increase in $T_{3}$ and $T_{4}$ secretion by an increment in oxygen consumption, and would not exclude a relation between iodohormone levels and thermogenesis during development.
\end{abstract}

\section{Introduction.}

It has been known for a long time that different incubation temperatures and variations in temperature during incubation can affect the growth and development of chick embryos, their hatching time and hatchability (Romanoff et al., 1938). These findings have been confirmed by Muambi (1974) and Michels et al. (1974), lower incubation temperafure always resulting in longer incubation. Several observations

* Supported by the Belgian « Nationaal Fonds voor Wetenschappelijk Onderzoek» (N. F. W. O.). 
indicate that thyroid hormones are involved in this process, for their injection increases rate of development and accelerates hatching time, whereas the injection of goitrogens decreases metabolic rate and retards hatching (Balaban and Hill, 1971 ; Freeman and Vince, 1974). Apparently, a certain level of thyroxine is necessary for the hatching of fowl, and the hypothesis has been put forward by Balaban and Hill (1971) that the thyroid hormones trigger this process. The same authors also showed that puncture of the chorioallantoic membrane must occur prior to hatching, although this membrane puncture does not guarantee that the embryo will hatch.

Recently, increasing levels of circulating triiodothyronine $\left(T_{3}\right)$ and thyroxine $\left(T_{4}\right)$ at the end of the incubation period have been reported (Daugeras-Bernard ef al., 1976a ; King et al., 1977 ; Thommes and Hylka, 1977), whereas an immediate posthatch drop of $T_{3}$ (King ef al., 1977) and $T_{4}$ (Thommes and Hylka, 1977) has been observed.

In the present study emphasis has been put on serum $T_{3}$ and $T_{4}$ levels before and during the processes of both pipping and hatching, and on their relation to the onset of pulmonary respiration. Different incubation temperatures were used to correlate the resulting incubation durations, hatching times and values of heat production to the serum $T_{3}$ and $T_{4}$ levels.

\section{Material and methods.}

Eggs from a pure-bred flock of approximately 1-year old Rhode Island Red hens were used. The fowls were housed with no temperature or humidity control. For each incubation experiment the total egg production of two consecutive days was used and stored in an air-conditioned room at about $10^{\circ} \mathrm{C}$ with $80 \mathrm{p.} 100$ relative humidity. 240 eggs, taken at random, were used for each experiment ; they were weighed, marked and incubated in a forced-draught laboratory incubator (Weiss Company, Giessen, Germany) as described by Michels et al. (1974) and turned every hour through an angle of $90^{\circ}$. The incubation temperature was constant to within $0.1{ }^{\circ} \mathrm{C}$. The ventilation rate was adapted to the incubation stage and to the number of living embryos. Humidity was kept constant at $30 \mathrm{~mm} \mathrm{Hg}$ during the whole experiment. The light was continuous at an intensity of 100 lux, and the eggs were candled on days 7 and 16 of incubation.

Four experiments were carried out at different incubation temperatures during the first 10 days since the chick embryo seems to be sensitive to thyroidogenic stimulation during this period (Freeman and Vince, 1974), and retardation or acceleration of incubation as primarily caused by different incubation temperatures at that time (Romanoff et al., 1938). The observed means for this period (2 observations/day) were $35.9 \pm 0.1^{\circ} \mathrm{C} ; 36.7^{\circ} \pm 0.2^{\circ} \mathrm{C} ; 37.8 \pm 0.1^{\circ} \mathrm{C}$ and $38.8 \pm 0.1^{\circ} \mathrm{C}$. From day 10 until hatching these means changed to $37.6 \pm 0 .{ }^{\circ} \mathrm{C} ; 37.5 \pm 0.1{ }^{\circ} \mathrm{C} ; 37.7 \pm 0.2{ }^{\circ} \mathrm{C}$ and $37.5 \pm 0.1^{\circ} \mathrm{C}$, respectively. So during this second part of incubation the temperature was about the same for each group.

As soon as possible, $\mathrm{O}_{2}$ and $\mathrm{CO}_{2}$ outputs were calculated by physical gas analysis data on a Noyons diaferameter (Kipp. Netherlands) at $25{ }^{\circ} \mathrm{C}$ with continuous registration on a BD5 micrograph according to the method described by Romijn and Lok- 
horst (1966) and adapted by Geers et al. (1978). Thermogenesis (T) was calculated using the formula of Barott et al. (1938) adapted by Romijn and Lokhorst (1961) : $\mathrm{T}=3.871 \mathrm{O}_{2}+1.194 \mathrm{CO}_{2}$. The calculation of heat production (Romijn and Lokhorst, 1961) was adapted for kJ.

From day 17 until pipping, about 10 embryos were killed every day. The blood samples were taken by cutting off the top of the heart ventricle; the same procedure was followed after hatching. These samples were allowed to clot, and then $T_{3}$ and $\mathrm{T}_{4}$ radioimmunoassays were performed using kits obtained from the Diagnostic Division of Abbott Pharmaceuticals. A good parallelism was obtained between serum dilution curves for $T_{3}$ and $T_{4}$ and the standard curves obtained with the commercial kits. ANS (8-anilino-1-naphtalenesulfonic acid) was added to promote the release of $T_{3}$ and $T_{4}$ from serum proteins such as thyroxinebinding globulin (TBG). Recovery values were good after the addition of both $T_{3}$ and $T_{4}$ to chicken serum (107 and 112 p. 100, respectively). The addition of $100 \mathrm{ng}$ of $T_{4}$ to the $T_{3}$ antiserum resulted in an inhibition equivalent to $0.7 \mathrm{ng}$ of $\mathrm{T}_{3}$, while adding $100 \mathrm{ng}$ of $\mathrm{T}_{3}$ to the $T_{4}$ antiserum caused an inhibition equivalent to $20.8 \mathrm{ng}$ of $\mathrm{T}_{4}$.

\section{Results.}

Heat production and respiratory quotient. - The result of both thermogenesis and respiratory quotient (RQ) are summarized in (fig. 1). The chick embryos incubated

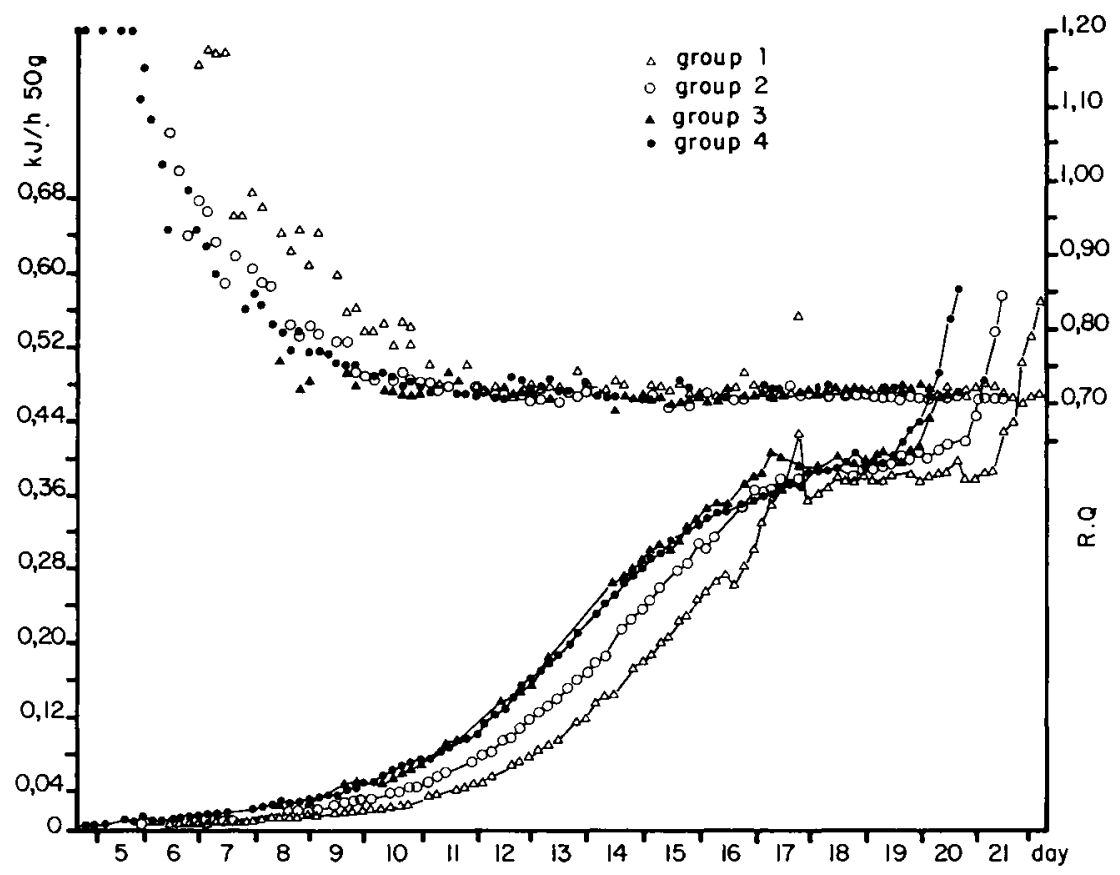

FIG. 1. - Heat production (thermogenesis) and respiratory quotient (R. Q.) of eggs incubated at different temperatures. Heat production is calculated every $4 \mathrm{hrs}$ and expressed in $\mathrm{kJ} / \mathrm{h} / 50 \mathrm{~g} \mathrm{egg}$. The total egg number for each temperature group is 240 . 


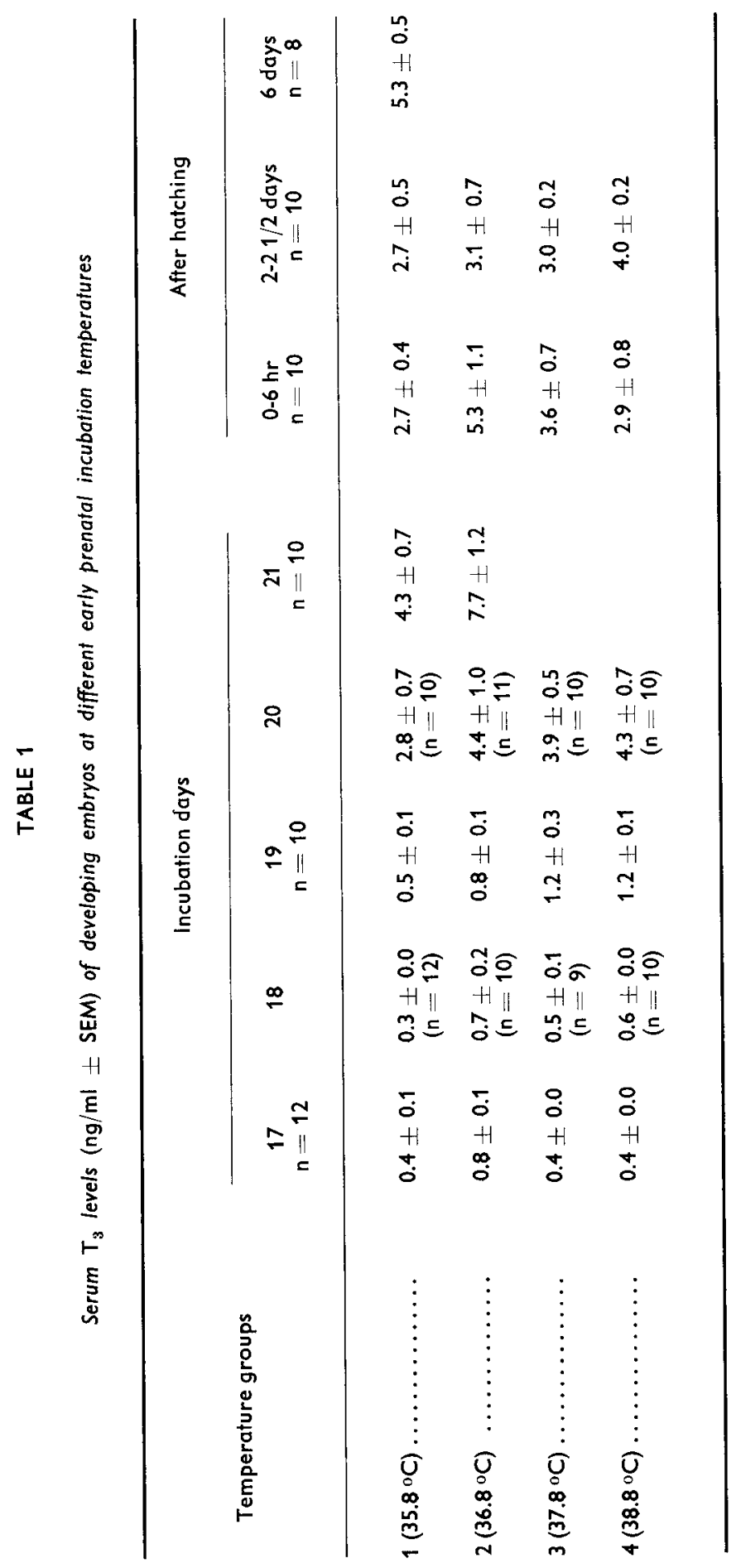




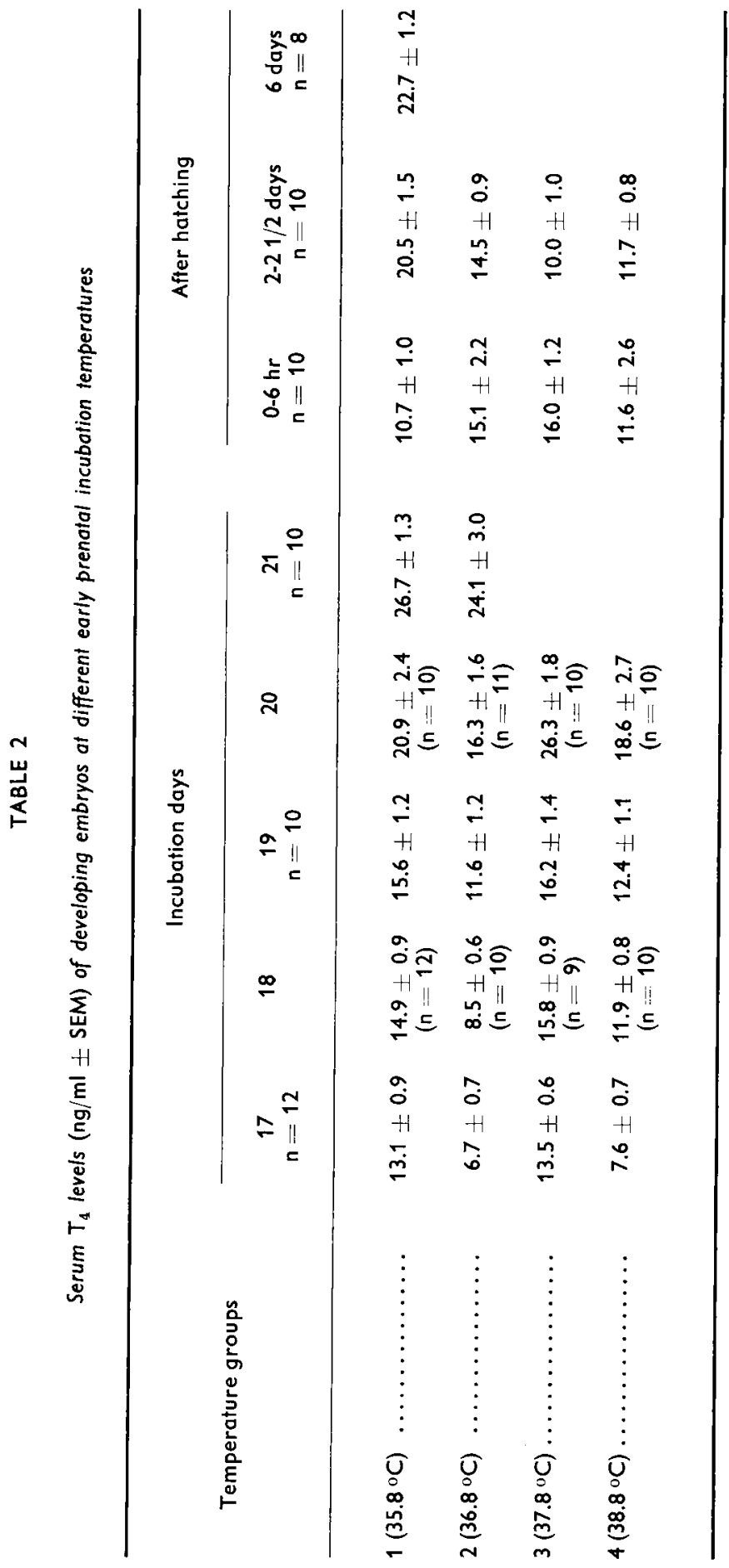


at a higher temperature showed an earlier increase in thermogenesis, but all the temperature groups reached a plateau around day 17. Eggs incubated at a higher temperature hatched sooner. The heat production between day 8 and the onset of pipping was the same for all the temperature groups $(63,65,65$ and $63 \mathrm{~kJ} / 50 \mathrm{~g}$ egg in groups 1 to 4 , respectively). A paired t-test made between all the groups for the calculated values (every $4 \mathrm{hrs}$ ) did not reveal any significant difference. This meant that the area, as defined under the four lines representing the thermogenesis of each temperature group in figure 1, was the same between day 8 and the day of pipping and hatching. After pipping, thermogenesis increased rapidly.

Up to days 6 to 7 , an $R Q$ value $>1$ was found in all of the groups, except in group $3\left(37.8^{\circ} \mathrm{C}\right)$ for which no values were available. Between days 6 to 7 and 10 to 11 , the $R Q$ decreased to 0.7 . After that, the $R Q$ in all the groups stabilized at about $R Q=0.7$ until the day of pipping and hatching.

$T_{3}$ and $T_{4}$ concentration in blood. - Serum $T_{3}$ and $T_{4}$ levels are summarized in tables 1 and 2 . Both these levels increased during the observed part of the incubation period and reached a maximum the day of pipping in all the incubation groups. Taking the day of hatching as day 0 , an analysis of variance of both the serum $T_{3}$ and $\mathrm{T}_{4}$ levels and the serum $\mathrm{T}_{3} / \mathrm{T}_{4}$ ratio, between days- 3 and +2.5 , showed highly significant statistical differences between days and temperature groups, and also a significant interaction between the two (table 3).

TABLE 3

Analysis of variance of serum $\mathrm{T}_{3}$ and $\mathrm{T}_{4}$ and $\mathrm{T}_{3} / \mathrm{T}_{4}$ ratio : $\mathrm{F}$-values

\begin{tabular}{|c|c|c|c|c|}
\hline Variable & $n$ & $\mathrm{~T}_{4}$ & $\mathrm{~T}_{3}$ & $\mathrm{~T}_{3} / \mathrm{T}_{4}$ \\
\hline 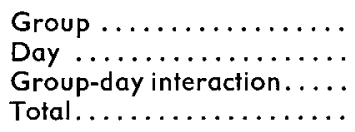 & $\begin{array}{r}4-1 \\
6-1 \\
15 \\
221\end{array}$ & $\begin{array}{r}23.21\left(^{a}\right) \\
38.81\left(^{a}\right) \\
2.24\left({ }^{b}\right)\end{array}$ & $\begin{array}{r}12.71\left(^{a}\right) \\
47.44\left(^{a}\right) \\
3.19\left(^{a}\right)\end{array}$ & $\begin{array}{r}16.15(a) \\
32.75(a) \\
3.01(a)\end{array}$ \\
\hline
\end{tabular}

$\left({ }^{a}\right) \mathrm{p} \leqslant 0.001$.

(b) $\mathrm{p} \leqslant 0.01$.

The $T_{3} / T_{4}$ ratio for the observed part of the incubation period is shown in figure 2 . In all the temperature groups, this ratio started increasing 2 days before the onset of pipping.

Serum $\mathrm{T}_{3}$ levels of the embryos having perforated the airspace membrane with the beak the day before pipping were higher in all of the temperature groups as compared to chicks without membrane perforation (table 4). For groups 1 and 4, the probability values were 0.09 ( 9 p. 100) and 0.11 (11 p. 100), respectively, with the non parametric Wilcoxon-Mann-Whitney or w-test (Wonnacott and Wonnacott, 1977) ; this is weak evidence for a higher $T_{3}$ value after membrane perforation, whereas this Pr-value was highly significant in groups 2 and 3 . The $T_{4}$ values did not differ, except 


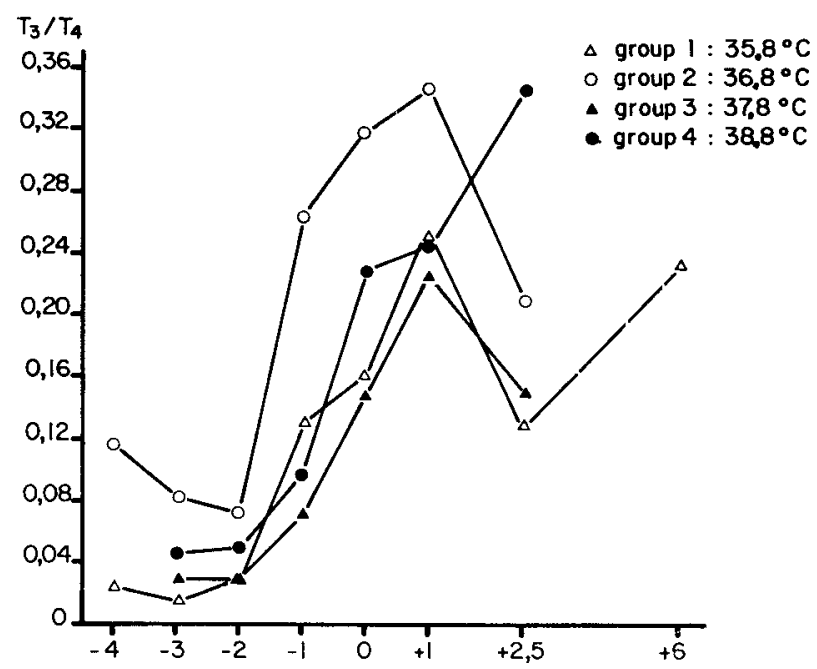

FIG. 2. - Comparison of the serum $T_{3} / T_{4}$ ratios of chick embryos incubated at different temperatures. Time reference 0 is the day of pipping for all groups whereas - or + do indicate the number of days before or after this event (mean of 10-12 observations) (see tables).

for temperature group $2\left(36.8^{\circ} \mathrm{C}\right)$ in which chicks having perforated the chorioallantoic membrane did have a significantly lower concentration as compared to chicks without perforation $(\mathrm{Pr} \leqslant 0.025)$.

\section{TABLE 4}

Comparison of serum $\mathrm{T}_{3}$ and $\mathrm{T}_{4}$ levels $(\mathrm{ng} / \mathrm{ml})$ in embryos having the bill in the air-chamber or not the day before the onset of pipping

\begin{tabular}{|c|c|c|c|c|c|c|c|}
\hline Temperature groups & $\mathrm{n}$ & $\mathrm{T}_{3}$ & w & $\operatorname{Pr}$ & $T_{4}$ & w & $\mathrm{Pr}$ \\
\hline \multirow[t]{2}{*}{$1\left(35.8^{\circ} \mathrm{C}\right) \ldots \ldots \ldots \ldots \ldots$} & 7 & $\bar{x}=3.6 \pm 0.9$ & 10 & 0.092 & $20.8 \pm 3.4$ & 14 & 0.33 \\
\hline & 3 & $\bar{Y}=0.9+0.3$ & & & $20.9 \pm 2.1$ & & \\
\hline \multirow[t]{2}{*}{$2\left(36.8^{\circ} \mathrm{C}\right) \ldots \ldots \ldots \ldots \ldots$} & 7 & $\bar{x}=5.3 \pm 1.4$ & 12 & 0.012 & $13.8 \pm 1.3$ & 13 & 0.021 \\
\hline & 4 & $\underline{\bar{Y}}=1.9 \pm 0.4$ & & & $20.6 \pm 2.7$ & & \\
\hline \multirow[t]{2}{*}{$3\left(37.8^{\circ} \mathrm{C}\right) \ldots \ldots \ldots \ldots$} & 3 & $\bar{X}:=2.4 \pm 0.8$ & 6 & 0.008 & $18.8 \pm 3.1$ & 12 & 0.192 \\
\hline & 7 & $\bar{Y}=0.7 \pm 0.1$ & & & $15.1 \pm 1.5$ & & \\
\hline \multirow[t]{2}{*}{$4\left(38.8^{\circ} \mathrm{C}\right) \ldots \ldots \ldots \ldots \ldots$} & 5 & $\bar{X}=1.4 \pm 0.2$ & 21 & 0.111 & $14.5 \pm 1.9$ & 23 & 0.210 \\
\hline & 5 & $\bar{Y}=1.0 \pm 0.2$ & & & $11.6 \pm 1.2$ & & \\
\hline
\end{tabular}

$\bar{X}$ : embryos with bill in air chamber (mean \pm SEM).

$\bar{Y}$ : embryos with bill outside air chamber (mean $\pm S E M$ ).

$\mathrm{n}$ : number of observations. trated.

$W$ : rank sum of the smaller sample, ranked from the end where this smaller sample is concen-

$\mathrm{Pr}$ : one-sided probability-value corresponding to the rank sum $\mathrm{W}$. 
After hatching, no significant change in serum $T_{3}$ levels was seen in any of the temperature groups as compared to the day of pipping. The $T_{4}$ level however dropped significantly in all the groups : $P \leqslant 0.001$ in groups $1\left(35.8^{\circ} \mathrm{C}\right)$ and $3\left(37.8^{\circ} \mathrm{C}\right)$ and $P \leqslant 0.05$ in groups $2\left(36.8^{\circ} \mathrm{C}\right)$ and $4\left(38.8^{\circ} \mathrm{C}\right)$. This hormonal difference resulted in a maximum $T_{3} / T_{4}$ ratio on the day of hatching, instead of pipping, for all the temperature groups except group 4 (38.8 ${ }^{\circ} \mathrm{C}$ ) (fig. 2).

Influence of sex. - No sex difference was seen in serum $T_{3}$ and $T_{4}$ levels in any of the groups studied, except for the $T_{3}$ level of group $2\left(36.8^{\circ} \mathrm{C}\right)$ in which the females had higher values on hatching day : $-1,0,+1$ and $+3.5(P \leqslant 0.05)$.

\section{Discussion.}

At the end of the incubation period, circulating $T_{3}$ and $T_{4}$ levels were found in the blood of developing chicks in agreement with the findings of Daugeras-Bernard et al. (1976a), King et al. (1977) and Thommes and Hylka (1977), but in contradiction with the data of Davison (1976) who reported that the total plasma $T_{4}$ level was highest on day 17 of incubation and declined thereafter until 1 day post-hatch. Our data on serum $\mathrm{T}_{3}$ and $\mathrm{T}_{4}$ in 0 to $6 \mathrm{~h}$ post-hatch chicks were of the same order of magnitude as the $T_{3}$ and $T_{4}$ concentrations found in 1-day old chicks by Thommes and Hylka (1977) (4.99 and $10.78 \mathrm{ng} / \mathrm{ml}$, respectively). Our data on serum $T_{3}$ and $T_{4}$ levels for 2 to $21 / 2$ day old chicks in most groups studied were slightly higher than those reported by Bobek et al. (1977) for 2-day old chicks (2.85 and $11 \mathrm{ng} / \mathrm{ml}$, respectively). Our experimental method showed that the hormonal maximum reached the day of pipping did not depend on the length of the incubation period since this differed according to the incubation temperature used, but was related to the hatching process itself.

The higher values of thyroid hormones in 6-day old chicks, as compared to hatched chicks or to 2 to $21 / 2$-day old chicks, are in agreement with the feedinginduced changes in most post-hatch chickens mentioned by King ef al. (1977).

The increase during the last incubation days was not the same for $T_{3}$ and $T_{4}$. We have observed that the blood ratio changes during development, with a mean low ratio of $0.06 \pm 0.04$ at day 17 for all the four temperature groups and a mean high ratio of $0.27 \pm 0.08$ on the day of hatching. The latter ratio is comparable to the $0.25 T_{3} / T_{4}$ ratio of Davison (1976) found in one-day old chicks. There are two possible explanations for this increased ratio :

a) thyroidal $T_{3}$ output increases. The presence of $T_{3}$ in the thyroid gland has been disputed in birds (Daugeras ef al., 1976b). However, $T_{3}$ has been found in the thyroglobulins of chick embryos by these authors ;

b) there is an increased conversion of serum $T_{4}$ to $T_{3}$. This conversion has been described for mammals (Sterling et al., 1970 ; Bernal and Escobar del Rey, 1975) and was suggested for cockerels subjected to cold (Kühn and Nouwen, 1978).

Apparently, the onset of pulmonary respiration is related to the presence of high circulating $T_{3}$ levels, as concluded from the serum level in embryos with or without the bill in the air chamber. For temperature group $2\left(36.8^{\circ} \mathrm{C}\right)$, we even found the indication of an increase in the peripheral conversion of $T_{4}$ to $T_{3}$, as suggested above. 
Here, the $T_{4}$ levels of embryos after membrane perforation were lower than before. In all other temperature groups, there was no difference in serum $T_{4}$ in embryos either with or without pulmonary respiration.

The total amount of heat production between day 8 and hatching was the same for all the temperature groups. This is in agreement with the findings of Barott (1937) who concluded that the total amount of heat produced during incubation did not depend on the incubation temperature. The high RQ values $(>1)$ until days 6 to 7 of incubation, and their progressive decrease from 1 to 0.7 between days 6 and 10 were in agreement with the data of other authors (Romijn and Lokhorst, 1951 ; Portet, 1960. 1961).

The following comments may be made with respect to the relation between serum $T_{3}$ and $T_{4}$ and thermogenesis : at a variable time, depending on the incubation temperature, a plateau for heat production is reached while the serum $T_{3}$ and $T_{4}$ levels are still increasing. According to Freeman and Vince (1974), who reviewed the literature and discussed their own data, this plateau could correspond to the maximal theoretical flux of $\mathrm{CO}_{2}$ and $\mathrm{O}_{2}$ through the egg shell membranes. This physical barrier would make it impossible for the embryo to react to an increase of serum $\mathrm{T}_{3}$ and $\mathrm{T}_{4}$ by augmenting $\mathrm{O}_{2}$ consumption and $\mathrm{CO}_{2}$ output, which are used in calculating the heat production. As seen in figure 1, an increase in heat production, corresponding to a maximum of serum $T_{3}$ and $T_{4}$, was observed the day of pipping when the physical barrier was lifted. On the basis of the previous findings and hypotheses, we expect there is a positive correlation between circulating thyroid hormones and heat production before and after the plateau observed.

\section{Conclusions.}

1) Increasing concentrations of serum $T_{3}$ and $T_{4}$ levels were found from day 17 of incubation until pipping, whatever the incubation temperature used. This was followed by a rather small post-hatch decrease.

2) Not only the serum $T_{3}$ and $T_{4}$ levels increased during the last incubation days of chick eggs, but there was a differential increase of both hormones resulting in an increased $T_{3} / T_{4}$ ratio until hatching.

3) The onset of pulmonary respiration was apparently related to an increase of $T_{3}$, but not of $T_{4}$, as concluded from the serum levels in embryos with or without the bill in the air-chamber.

4) Our data on heat production confirm the findings of Barrott (1937) who concluded that the total amount of heat produced during incubation was the same under different incubation temperatures.

5) A plateau in heat production was observed during the last incubation days before pipping, whereas serum $\mathrm{T}_{3}$ and $\mathrm{T}_{4}$ levels were increasing considerably. This could be explained by a maximal theoretical flux of $\mathrm{CO}_{2}$ and $\mathrm{O}_{2}$ through the physical barrier of the eggs shell and the membranes. 
Acknowledgments. - We would like to thank the Diagnostic Division of Abbott Pharmaceuticals (Antwerp) for providing the kits for the radioimmunoassay of the $T_{3}$ and $T_{4}$. The technical assistance of Mr. A. Vlaeyen and Mrs. Ghilain-Nackaerts is gratefully acknowledged.

Résumé. Les concentrations plasmatiques de triiodothyronine $\left(T_{3}\right)$ et de thyroxine $\left(T_{4}\right)$ ont été mesurées par RIA dans des embryons de poulet d'une souche Rhode Island Red incubés à différentes températures dans un incubateur à air pulsé. Une température basse entraîne une durée d'incubation longue, tandis que l'éclosion a lieu plus tôt si les œufs sont incubés à des températures plus élevées. Quelle que soit la température d'incubation, les concentrations de $T_{3}$ ef $T_{4}$ dans le sérum augmentent durant la période d'incubation étudiée. Quelle que soit la durée d'incubation, les concentrations hormonales sériques maximums se situent toujours le jour du bêchage. Les embryons ayant percé la chambre à air le jour précédent montraient des concentrations de $T_{3}$ nettement plus élevées (mais non de $T_{4}$ ) que ceux ne l'ayant pas encore perforée. La présence de concentration élevée de $T_{3}$ ef l'augmentation rapide de la proportion $\mathrm{T}_{3} / \mathrm{T}_{4}$ après la rupture de la chambre à air semblent indiquer que $T_{3}$ joue un rôle important dans les événements préparatoires à l'éclosion. Un plateau dans la thermogenèse a été constaté par calorimétrie indirecte après le $16^{\mathrm{e}}$ ou 17 jour (selon la température d'incubation), bien que les concentrctions de $T_{3}$ ef $T_{4}$ dans le sérum continuaient à augmenter. Après le percement de la coquille, la thermogenèse augmente rapidement. La présence d'un plateau dans la thermogenèse pourrait être due à une impossibilité physique des embryons de réagir à une sécrétion accrue d'hormones thyroïdiennes par une augmentation de consommation d'oxygène et n'exclut donc pas la possibilité d'une relation entre les iodohormones dans le sérum ef la thermogenèse au cours du développement.

\section{References}

BALABAN M., HILL J., 1971. Effects of thyroxine level and temperature manipulations upon the hatching of chick embryos (Gallus domesticus). Develop. Psychobiol., 4, 17-35.

BAROTT H. G., 1937. Effect of temperature, humidity and other factors on hatch of hens eggs and on energy metabolism of chick embryos. U. S. Dept. Agric. tech. Bull., 553.

BAROTT H. G., FRITZ C. Y., PRINGLE E. M., TITUS H. W., 1938. Heat production and gaseous metabolism of young male chickens. J. Nutr., 15, 145-167.

BERNAL J., ESCOBAR DEL REY F., 1975. Effect of the exposure to cold on the extrathyroidal conversion of L-thyroxine to triiodo-L-thyronine and on intramitochondrial $\alpha$-glycero-phosphate dehydrogenese activity in thyroidectomized rats on L-thyroxine. Acta endocr., 78, 481-492.

BOBEK S., JASTRZEBSKI M., PIETRAS M., 1977. Age-related changes in oxygen consumption and plasma thyroid hormone concentration in the young chicken. Gen. comp. Endocrinol., 31, 169-174.

DAUGERAS N., BRISSON A., LAPOINTE-BOULU F., LACHIVER F., 1976b. Thyroidal iodine metabolism during the development of the chick embryo. Endocrinology, 93, 1321-1331.

DAUGERAS-BERNARD N., LELOUP J., LACHIVER F., 1976a. Evolution de la thyroxinémie au cours du développement de l'embryon de poulet. Influence de l'hypophysectomie. C. R. Acad. Sci. Paris, Sér. D, 283, 1325-1329.

DAVISON T. F., 1976. Circulating thyroid hormones in the chicken before and after hatching. Gen. comp. Endocrinol., 29, 21-28.

FREEMAN B. M., VINCE A. M., 1974. Development of the avian embryo. Ed. Chapman and Hall, London.

GEERS R., MICHELS H., DECUYPERE E., 1978. Advances in a method for gas analysis in metabolic experiments : improved calibration of a Noyons diaferometer. Ann. Biol. anim. Biochim. Biophys., 18, 1309-1315. 
KING D. B., KING C. R., ESCHLEMAN J. R., 1977. Serum Triiodothyronine Levels in the Embryonic and Post-Hatching Chicken, with Particular Reference to Feeding-Induced Changes. Gen. comp. Endocrinol., 31, 216-223.

KUHN E. R., NOUWEN E. J., 1978. Serum levels of triiodothyronine and thyroxine in the domestic fowl following mild cold exposure and injection of synthetic thyrotropin releasing hormone. Gen. comp. Endocrinol., 34, 336-342.

MICHELS H., GEERS R., MUAMBI S., 1974. The effect of incubation temperature on pre- and post hatching development in chickens. Br. Poult. Sci., 15, 517-523.

MUAMB| S., 1974. Etude de critères de croissance prénatale et postnatale chez la race de volaille « Rhode Island Red » en fonction de differentes températures environnantes. Agricultura, 22, 1-56.

PORTET R., 1960. Effet de la thyroxine sur les échanges respiratoires de l'embryon de poulet. J. Physiol. Path. gén., 52, 200-201.

PORTET R., 1961. Les échanges respiratoires de l'embryon du poulet. Action de quelques agents physiques et biochimiques. A. Legrand et Cie, eds., Paris.

ROMANOFF A. L., SMITH L. L., SULLIVAN R. A., 1938. Biochemistry and biophysics of the developing hen's egg. Il. Influence of temperature. Corn. Univ. Agric. exp. Stot. Mem., 216, 1-42.

RO.UIJN C., LOKHORST W., 1951. Foetal respiration in the hen. The respiration metabolism of the embryo. Phys. comp. Oecol., 2, 187-197.

ROMIJN C., LOKHORST W., 1961. Some aspects of energy metabolism in birds. II th Symp. Energy Metabolism, public. 10, 49-59.

ROM!JN C., LOKHORST W., 1966. Improved gas analysis in metabolic experiments. Acta physiol. pharmacol. neerl., 14, 1-11.

STERLING K., BRENNER M. A., NEWMAN E. S., 1970. Conversion of thyroxine to triiodothyronine in normal human subjects. Science, 169, 1099-1100.

THOMMES R. C., HYLKA V. W., 1977. Plasma lodothyronines in the embryonic and Immediate post-hatch chick. Gen. comp. Endocrinol., 32, 417-422.

WONNACOTT T. H., WONNACOTT R. J., 1977. Introductory Statistics. John Wiley and Sons, New York. 